\title{
Challenges and Opportunities: A Report of the 1998 Library Survey of Internet Users at Seton Hall University
}

\section{Xue-Ming Bao}

This survey aims to collect data to enable Seton Hall University librarian faculty and administration to analyze user satisfaction with information services provided through the Internet's World Wide Web. Seton Hall faculty and students completed 786 questionnaires. About 80 percent of the respondents reported that they used the Web on a daily or weekly basis. The results reveal valuable information about the Internet users' search strategies and their levels of satisfaction in using the Web. Analysis of the data suggests three challenges for academic librarians and five opportunities in providing Internet information services.

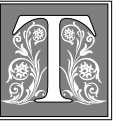

he Internet has become an important component of electronic services in academic libraries. In an ALA survey, Mary J. Lynch reported that 87 percent of academic libraries of doctorate-granting institutions included in the survey provided information access through home pages on the Web; 84 percent provided formal Internet training for faculty; and 90 percent provided student training. ${ }^{1}$ In a national survey sponsored by the U.S. National Commission on Libraries and Information Science, researchers John C. Bertot, Charles R. McClure, and Douglas L. Zweizig reported that the top three most important benefits of connecting to the Internet were the ability of libraries to: (1) access electronic Internet-based information; (2) communicate with other professionals, libraries, and the public; and (3) enhance reference service capabilities. ${ }^{2}$
Seton Hall University Library created its home pages in 1995. ${ }^{3}$ The initial focus of the site was to provide information access to library services and resources. These resources include the library's online catalog (SetonCat), periodical title database, CD-ROM listing, and descriptions of various library services. The 1995 pages also included a limited number of online resources including Encyclopaedia Britannica and Project Muse.

In October 1997, the library's home pages were restructured and redesigned under the leadership of Arthur W. Häfner, dean of university libraries. The URL for the library Web site is <www.shu.edu/ library $>$. The new structure and design strategically focus on gateway access to worldwide academic resources. In addition, the site strengthens the base of local information featured in the earlier home pages. The revitalized site extends be-

Xue-Ming Bao is Assistant Professor/Reference Librarian in the University Library at Seton Hall University; e-mail: baoxuemi@shu.edu. 


\begin{tabular}{|lrc|}
\hline \multicolumn{3}{|c|}{ TABLE 1 } \\
Students and Faculty Com- \\
pleting the Survey (question 1) \\
\hline \multicolumn{4}{c}{ No. } & \% \\
\hline Undergraduate & 596 & $75.8 \%$ \\
Graduate & 160 & 20.4 \\
Faculty & 30 & 3.8 \\
Total & 786 & 100.0 \\
\hline
\end{tabular}

yond the resources that are physically available in the library.

This increased access raises two key questions: (1) How does the new site meet the needs of students and faculty at the university? (2) What strategies should the university librarians pursue to improve global access to information services through the Web?

\section{Purpose}

The purpose of this survey is to collect data that will enable the university librarian faculty and administration to analyze student and faculty satisfaction with gateway global information services provided through the Web. This study is a descriptive survey. ${ }^{4}$ It is concerned primarily with certain aspects of student and faculty use of the Internet's Web. The objective of the study, in general terms, is to serve as "an aid ... in planning, improving public relations, and even marketing. ${ }^{\prime 5}$

\section{Survey Instrument}

The survey instrument described in this research was pilot-tested by eight persons: four students, two faculty members, and two outside readers. It was modified based on their responses and suggestions. The instrument attempts to elicit answers to the following questions:

1. Who is using the Internet and the library's home pages?
2. What are the user's academic majors or fields of study?

3. How frequently does the user search the Internet?

4. What does the user search for on the Internet?

5. What is the user's satisfaction level with search results?

6. How long does it take the user to find "satisfactory" results?

7. What problems has the user encountered when searching the Internet?

8. Has the user visited the library's home pages?

9. Does the user find the library's home pages helpful in searching the Internet?

10. How does the user find information on the Internet?

11. What are the user's favorite Internet search engine(s)?

12. Academically, whose responsibility is it to teach the user how to search the Internet effectively?

13. What training courses would the user attend?

\section{Data Collection}

In Applied Statistics, John Neter, William Wasserman, and G. A. Whitemore state that a census of a finite population is a study that includes every element of the population, and a census is appropriate when it is easy to reach everyone included in the study. ${ }^{6}$ In Descriptive Statistical Techniques for Librarians, Arthur W. Häfner

\begin{tabular}{|c|c|c|c|c|c|c|c|c|}
\hline \multicolumn{9}{|c|}{$\begin{array}{c}\text { TABLE } 2 \\
\begin{array}{c}\text { Students and Faculty and Their Academic } \\
\text { Major or Field (question 2) }\end{array} \\
\end{array}$} \\
\hline & \multicolumn{2}{|c|}{ Undergraduate } & \multicolumn{2}{|c|}{ Graduate } & \multicolumn{2}{|c|}{ Faculty } & \multicolumn{2}{|c|}{$\mathrm{n}=786$} \\
\hline & $\mathrm{N}$ & $\%$ & $\mathrm{~N}$ & $\%$ & $\mathrm{~N}$ & $\%$ & $\mathrm{~N}$ & $\%$ \\
\hline Arts \& Sciences & 297 & 37.8 & 39 & 5.0 & 15 & 1.9 & 351 & 44.7 \\
\hline Business & 158 & 20.1 & 21 & 2.7 & 4 & 0.5 & 183 & 23.3 \\
\hline Diplomacy & 1 & 0.1 & 0 & 0.0 & 0 & 0.0 & 1 & 0.1 \\
\hline Education & 104 & 13.2 & 32 & 4.1 & 7 & 0.9 & 143 & 18.2 \\
\hline Medical Education & n 10 & 1.3 & 21 & 2.7 & 1 & 0.1 & 32 & 4.1 \\
\hline Nursing & 8 & 1.0 & 31 & 3.9 & 2 & 0.3 & 41 & 5.2 \\
\hline Theology & 1 & 0.1 & 11 & 1.4 & 1 & 0.1 & 13 & 1.6 \\
\hline Other & 17 & 2.2 & 4 & 0.5 & 0 & 0.0 & 21 & 2.7 \\
\hline
\end{tabular}




\begin{tabular}{|c|}
\hline TABLE 3 \\
Student and Faculty Using the Web on the Internet \\
(question 3)
\end{tabular}

\begin{tabular}{|c|c|c|c|c|c|c|c|c|}
\hline & \multicolumn{2}{|c|}{ Undergraduate } & \multicolumn{2}{|c|}{ Graduate } & \multicolumn{2}{|c|}{ Faculty } & \multicolumn{2}{|c|}{$\mathrm{n}=786$} \\
\hline & $\mathrm{N}$ & $\%$ & $\mathrm{~N}$ & $\%$ & $\mathrm{~N}$ & $\%$ & $\mathrm{~N}$ & $\%$ \\
\hline Daily & 241 & 30.7 & 56 & 7.1 & 19 & 2.4 & 316 & 40.2 \\
\hline Weekly & 238 & 30.3 & 57 & 7.3 & 6 & 0.8 & 301 & 38.4 \\
\hline Monthly & 63 & 8.0 & 18 & 2.3 & 3 & 0.4 & 84 & 10.7 \\
\hline Yearly & 5 & 0.6 & 0 & 0.0 & 0 & 0.0 & 5 & 0.6 \\
\hline Seldom & 32 & 4.1 & 19 & 2.4 & 1 & 0.1 & 52 & 6.6 \\
\hline Never & 15 & 1.9 & 9 & 1.1 & 1 & 0.1 & 25 & 3.1 \\
\hline
\end{tabular}

- a statement of anonymity/confidentiality of the subject's data.

Each faculty member was asked for his or her cooperation for the following activities:

1. completing the questionnaire;

2. selecting one or more classes of students randomly from their teaching assignment;

3. distributing the cop-

states: "Whether the population is sampled or surveyed completely (census), the librarian will want to apply algorithms to reorganize and summarize the raw data." 7 This author collected the survey data by means of a census of 450 teaching faculty members who are listed in Seton Hall University Registration Handbook, Spring 1998: Undergraduate and Graduate Course Offerings. This handbook contains a listing of the courses offered in the 1998 spring semester and identifies the names of the teaching faculty. It covers the seven academic colleges served by the library (Arts \& Sciences, Business, Diplomacy, Education, Medical Education, Nursing, and Theology). Because the average class size at the university is twentyfive students, ${ }^{8}$ twenty-five copies of the questionnaire were sent through the campus mail to each of the 450 faculty members listed in the handbook. Cover letters to faculty and students stated:

- the researcher's affiliation with the university;

- a brief description of the project;

- a statement of the voluntary nature of the project; ies of the cover letter and questionnaire to students;

4. allowing students five to ten minutes to complete the questionnaire;

5. collecting the completed questionnaires and returning them to the researcher through the campus mail.

Survey instruments were distributed the week after the university's spring recess (March 16, 1998). Between March 19 and May 7, 1998, seventy-seven faculty members, or 17 percent of the 450 included in the study, returned 786 completed questionnaires. In situations where a student received the questionnaire in more than one class, he or she was instructed to complete only one survey. Twenty-eight $(6 \%$ of the 450$)$ of the returns were invalid because of undeliverable campus mail. Apossiblecause may havebeen a mismatch between the names of the faculty and their department addresses. The author inferred what department a faculty member might be in according to the descriptions in the registration handbook of the courses that he or she teaches.

In Survey Research Methods, Floyd J. Fowler Jr. remarked that a 5 to 20 percent

\begin{tabular}{|c|c|c|c|c|}
\hline \multicolumn{5}{|c|}{$\begin{array}{c}\text { TABLE } 4 \\
\text { Students and Faculty Searching Information on Academic and Nonacademic } \\
\text { Studies (question 4) }\end{array}$} \\
\hline & Undergraduate & Graduate & Faculty & $\mathrm{n}=786$ \\
\hline & $\mathrm{N} \quad \%$ & $\mathrm{~N} \quad \%$ & $\mathrm{~N} \quad \%$ & $\mathrm{~N} \quad \%$ \\
\hline Inforr & 50063.6 & $128 \quad 16.3$ & 3.3 & $654 \quad 83.2$ \\
\hline Information not related to academic studies & s $455 \quad 57.8$ & $106 \quad 13.5$ & $20 \quad 2.5$ & 58173.8 \\
\hline
\end{tabular}




\begin{tabular}{|c|c|c|c|c|c|c|c|c|}
\hline \multicolumn{9}{|c|}{$\begin{array}{c}\text { TABLE } 5 \\
\text { Student and Faculty Levels of Satisfaction for Internet Search } \\
\text { Results (question 5) } \\
\end{array}$} \\
\hline & \multicolumn{2}{|c|}{ Undergraduate } & \multicolumn{2}{|c|}{ Graduate } & \multicolumn{2}{|c|}{ Faculty } & \multicolumn{2}{|c|}{$\mathrm{n}=786$} \\
\hline & $\mathrm{N}$ & $\%$ & $\mathrm{~N}$ & $\%$ & $\mathrm{~N}$ & $\%$ & $\mathrm{~N}$ & $\%$ \\
\hline 1 (High Satisfaction) & 44 & 5.6 & 12 & 1.5 & 5 & 0.6 & 61 & 7.7 \\
\hline 2 & 228 & 29.0 & 48 & 6.1 & 8 & 1.0 & 284 & 36.1 \\
\hline 3 & 217 & 27.6 & 66 & 8.4 & 8 & 1.0 & 291 & 37.0 \\
\hline 4 & 70 & 8.9 & 19 & 2.4 & 4 & 0.5 & 93 & 11.8 \\
\hline 5 (Low Satisfaction) & 19 & 2.4 & 2 & 0.3 & 3 & 0.4 & 24 & \\
\hline
\end{tabular}

response rate is low, but he also states: "There is no agreed-upon standard for a minimum acceptable response rate. . . One generalization that seems to hold up for most mail surveys, though it is inferential, is that people who have a particular interest in the subject matter or the research itself are more likely to return mail questionnaires than those who are less interested. This means that mail surveys with low response rates may be biased significantly in ways that are related directly to the purposes of the research." ${ }^{\prime 9}$ With this caution in mind, the author qualifies the survey projection to the faculty and students who are interested in using the Internet only, rather than the entire population of the university.

To analyze the data, the Statistical Package for the Social Sciences (SPSS) was employed. Data from the survey instruments were coded and subjected to SPSS. Frequency tabulations were applied to obtain descriptive measures of the responses.

\section{Results}

\section{User Demographics}

Table 1 shows that of the 786 survey instruments, $596(75.8 \%)$ were completed and returned to the author from undergraduate students, $160(20.4 \%)$ from graduate students, and $30(3.8 \%)$ from faculty members.

Table 2 shows that most responses $(677$, or
$86.2 \%$ ) were from three academic majors: arts \& sciences (351, or $44.7 \%)$, business $(183$, or $23.3 \%)$, and education $(143$, or $18.2 \%)$. Other responses $(87$, or $11 \%$ ) were from academic majors including nursing $(41$, or $5.2 \%)$, medical education $(32$, or $4.1 \%)$, theology $(13$, or $1.7 \%)$, and diplo$\operatorname{macy}(1$, or $0.1 \%)$.

\section{Internet Use Frequency and Satisfaction Levels}

Table 3 shows that most respondents used the Web on a daily (316, or $40.2 \%)$, weekly $(301$, or $38.3 \%)$, and monthly (84, or $10.7 \%$ ) basis. Seventy-seven respondents (about 10\%) said they seldom or never used the Internet.

Table 4 shows that students and faculty searched the Internet for information related to both their academic $(654$, or $83.2 \%)$ and nonacademic studies (581, or $73.8 \%$ ).

On a scale of five levels of satisfaction, one is used to indicate the highest level and five the lowest. In table 5, most respondents placed their levels of satisfaction for Internet search results at level two $(284$, or $36.1 \%)$ and level three $(291$, or

\section{TABLE 6}

\section{Student and Faculty Time Spent on Searching Satisfactory Results per Session (question 6)}

\begin{tabular}{lrrrrrrrrr}
\hline \hline & \multicolumn{1}{c}{ Undergraduate } & \multicolumn{1}{c}{ Graduate } & \multicolumn{1}{c}{ Faculty } & \multicolumn{2}{c}{$\mathrm{n}=786$} \\
& $\mathrm{~N}$ & $\%$ & $\mathrm{~N}$ & $\boldsymbol{\%}$ & $\mathrm{N}$ & $\%$ & $\mathrm{~N}$ & $\%$ \\
\hline 5-10 minutes & 30 & 3.8 & 6 & 0.8 & 3 & 0.4 & 39 & 5.0 \\
$11-20$ minutes & 142 & 18.1 & 33 & 4.2 & 10 & 1.3 & 185 & 23.6 \\
$21-30$ minutes & 190 & 24.2 & 44 & 5.6 & 7 & 0.9 & 241 & 30.7 \\
$31+$ minutes & 192 & 24.4 & 63 & 8.0 & 9 & 1.1 & 264 & 33.5 \\
\hline
\end{tabular}




\begin{tabular}{|c|c|c|c|c|c|c|c|}
\hline $\begin{array}{r}\text { Student and Faculty Probl } \\
\text { Inteı }\end{array}$ & $\begin{array}{r}\text { TA } \\
\text { lems } \\
\text { ernet } \\
\end{array}$ & $\begin{array}{l}\text { BLE } 7 \\
\text { Encoun } \\
\text { (questio }\end{array}$ & $\begin{array}{l}\text { ntere } \\
\text { on 7) }\end{array}$ & d W & en Se & & \\
\hline & Jnder & raduate & Grad & uate & Faculty & & 786 \\
\hline & $\mathrm{N}$ & $\%$ & $\mathrm{~N}$ & $\%$ & $\mathrm{~N} \%$ & $\mathrm{~N}$ & $\%$ \\
\hline Too many hits & 230 & 29.3 & 59 & 7.5 & 131.7 & 302 & 38.5 \\
\hline Do not find information needed & 302 & 38.4 & 69 & 8.8 & 162.0 & 387 & 49.2 \\
\hline $\begin{array}{l}\text { No full-text information can be } \\
\text { cited for academic study and/or } \\
\text { research }\end{array}$ & 268 & 34.1 & 64 & 8.1 & 121.5 & 344 & 43.7 \\
\hline Other & 103 & 13.1 & 20 & 2.5 & 50.6 & 128 & 16.2 \\
\hline
\end{tabular}

$37 \%)$. Only $61(7.7 \%)$ of the respondents indicated a high level of satisfaction, and 117 (about 15\%) indicated low levels (levels 4 and 5) of satisfaction.

\section{Internet Search Results and Problems}

Table 6 shows that 185 (23.6\%) of respondents spent 11 to 20 minutes on searching to obtain satisfactory results, 241 (30.7 $\%$ ) spent 21 to 30 minutes, and 264 (33.5\%) spent $30+$ minutes. Only $39(5 \%)$ of the respondents achieved satisfactory results in less than 10 minutes.

Table 7 identifies three major problems encountered by users when searching the Internet:

1. do not find information needed (387, or $49.2 \%)$;

2. no full-text information can be cited for academic study and/or research (344, or $43.7 \%$ );

3. too many hits $(302$, or $38.5 \%)$.

\section{Use of University Library Home Pages}

Table 8 shows that less than half of the respondents $(325$, or $41.4 \%)$ visited the library's home pages when conducting their research.
Table 9 shows that of the $321(40.9 \%)$ respondents who accessed the library's home pages, 151 (19.2\%) felt the home pages were helpful, $108(13.8 \%)$ somewhat helpful, 42 (5.4\%) very helpful, and $20(2.5 \%)$ not helpful.

\section{Internet Search Strategies}

Table 10 shows that students and faculty $(657$, or $83.6 \%)$ regard using Internet search engines as a preferred way to search the Internet, followed by directly entering a URL or Web address (502, or $63.9 \%$ ). Using categorized gateway Internet resource listings $(140$, or $17.8 \%$ ) and subscription databases $(95$, or $12.1 \%$ ) were alternate ways of searching the Internet. An explanation for the relatively low use of the subscription databases is that they had only been available on the library's home pages for less than two months before the survey was conducted.

Table 11 shows that Yahoo is the favorite Internet search engine among the Internet users $(633$, or $80.5 \%)$. Other preferred search engines were InfoSeek (284, or $36.2 \%)$, Excite $(218$, or $27.7 \%)$, Alta Visa (217, or $27.6 \%)$, WebCrawler (154, or $19.6 \%)$, and Lycos (134, or $17 \%)$. The least used Internet search engines were Hotbot $(30$, or $3.8 \%)$, MetaCrawler (18, or $2.3 \%)$, and Open Text Index $(8$, or $1 \%)$.

\section{Internet Search Training}

Table 12 shows the opinions of respondents concerning 


\begin{tabular}{|c|c|c|c|c|c|c|c|c|}
\hline \multicolumn{9}{|c|}{$\begin{array}{c}\text { TABLE } 9 \\
\text { Student and Faculty Opinions on the Library's Home } \\
\text { Pages in Facilitating Internet Searches (question 9) } \\
\end{array}$} \\
\hline & \multirow{2}{*}{\multicolumn{2}{|c|}{$\begin{array}{c}\text { Undergraduate } \\
\text { N } \%\end{array}$}} & \multicolumn{2}{|c|}{ Graduate } & \multicolumn{2}{|c|}{ Faculty } & \multicolumn{2}{|c|}{$\mathrm{n}=786$} \\
\hline & & & $\mathrm{N}$ & $\%$ & $\mathrm{~N}$ & $\%$ & & \\
\hline Very Helpful & 24 & 3.1 & 13 & 1.7 & 5 & 0.6 & 42 & 5.4 \\
\hline Helpful & 119 & 15.1 & 22 & 2.8 & 10 & 1.3 & 1511 & 19.2 \\
\hline Somewhat helpful & 91 & 11.6 & 14 & 1.8 & 3 & 0.4 & 1081 & 13.8 \\
\hline Not helpful & 15 & 1.9 & 4 & 0.5 & 1 & 0.1 & 20 & 2.5 \\
\hline
\end{tabular}

which persons or agencies within the university should be responsible for teaching them how to search the Internet effectively. The responses were:

- university computing services (350, or $44.5 \%)$;

- $\quad$ academic college (310, or $39.5 \%)$;

- university librarian faculty $(147$, or $18.7 \%)$;

- other $(124$, or $15.8 \%)$.

A significant number of respondents who marked "other" commented that they felt it a personal responsibility to learn to search the Internet effectively. More faculty members in the survey identified the responsibility as belonging to the librarian faculty (10 out of 30 , or $33.3 \%$ ) than to the academic college ( 3 out of 30 , or $10 \%$ ). Undergraduate students identified the responsibility as belonging to academic colleges ( 271 out of 596 , or $45.5 \%$ ) rather than the librarian faculty (92 out of 596 , or $15.4 \%$ ).

Table 13 identifies which Internet training courses the respondents would likely attend if the courses were offered by the librarian faculty. Respondents indicated that they were most interested in learning advanced Internet searching skills (434, or $55.2 \%$ ), followed by basic Internet searching (347, or $44.2 \%$ ), gateway Internet resource listings (240, or $30.6 \%)$, and subscription databases (192, or $24.4 \%$ ).

\section{Discussion \\ Challenges}

The main challenge for Seton Hall University librarians appears to be how to raise the users' level of satisfaction when providing information services through the Internet. The Internet has become an important source of information for academic studies as demonstrated in the survey that 617 (78.5\%) of the 786 student and faculty respondents used it on a daily or weekly basis. Although the Internet has great potential as a delivery system for both information and instruction, 77 (about $10 \%$ ) students and faculty indicated they had seldom or never used the Internet. The study also showed that only

\begin{tabular}{|c|c|c|c|c|c|c|c|}
\hline \multicolumn{8}{|c|}{$\begin{array}{l}\text { TABLE } 10 \\
\text { Students and Faculty Searching the Internet in Different Ways } \\
\text { (question 10) }\end{array}$} \\
\hline & \multicolumn{2}{|c|}{ Undergraduate } & \multicolumn{2}{|c|}{ Graduate } & Faculty & \multicolumn{2}{|c|}{$\mathrm{n}=786$} \\
\hline & $\mathrm{N}$ & $\%$ & $\mathrm{~N}$ & $\%$ & $\mathrm{~N} \%$ & $\mathrm{~N}$ & $\%$ \\
\hline Use Internet search engines & 514 & 65.4 & 118 & 15.0 & 253.2 & 657 & 83.6 \\
\hline Type in a Web address directly & 388 & 49.4 & 89 & 11.3 & 253.2 & 502 & 63.9 \\
\hline $\begin{array}{l}\text { Use categorized gateway Internet } \\
\text { resource listings }\end{array}$ & 102 & 13.0 & 30 & 3.8 & 81.0 & 140 & 17.8 \\
\hline Use subscription databases & 70 & 8.9 & 19 & 2.4 & 60.8 & 95 & 12.1 \\
\hline Other & 12 & 1.5 & 6 & 0.8 & 00.0 & 18 & 2.3 \\
\hline
\end{tabular}




\begin{tabular}{|c|c|c|c|c|c|c|c|c|}
\hline \multicolumn{9}{|c|}{$\begin{array}{c}\text { TABLE 11 } \\
\begin{array}{c}\text { Students' and Faculty's Favorite Internet Search } \\
\text { Engines (question 11) }\end{array}\end{array}$} \\
\hline & \multicolumn{2}{|c|}{ Undergraduate } & \multicolumn{2}{|c|}{ Graduate } & \multicolumn{2}{|c|}{ Faculty } & \multicolumn{2}{|c|}{$\mathrm{n}=786$} \\
\hline & $\mathrm{N}$ & $\%$ & $\mathrm{~N}$ & $\%$ & $\mathrm{~N}$ & $\%$ & $\mathrm{~N}$ & $\%$ \\
\hline Alta Visa & 164 & 20.9 & 41 & 5.2 & 12 & 1.5 & 217 & 27.6 \\
\hline Excite & 173 & 22.0 & 37 & 4.7 & 8 & 1.0 & 218 & 27.7 \\
\hline Hotbot & 21 & 2.7 & 9 & 1.1 & 0 & 0.0 & 30 & 3.8 \\
\hline InfoSeek & 226 & 28.8 & 48 & 6.1 & 10 & 1.3 & 284 & 36.2 \\
\hline Lycos & 109 & 13.9 & 20 & 2.5 & 5 & 0.6 & 134 & 17.0 \\
\hline MetaCrawler & 12 & 1.5 & 6 & 0.8 & 0 & 0.0 & 18 & 2.3 \\
\hline Open Text Index & 5 & 0.6 & 2 & 0.3 & 1 & 0.1 & 8 & 1.0 \\
\hline Yahoo & 496 & 63.1 & 115 & 14.6 & 22 & 2.8 & 633 & 80.5 \\
\hline WebCrawler & 129 & 16.4 & 23 & 2.9 & 2 & 0.3 & 154 & 19.6 \\
\hline Other & 18 & 2.3 & 5 & 0.6 & 2 & 0.3 & 25 & 3.2 \\
\hline
\end{tabular}

$61(7.7 \%)$ of the respondents indicated a high level of satisfaction with the Internet. Even though 426 (54.3\%) students and faculty were able to obtain satisfactory results within a period of 11 to 30 minutes, most $(575$, or $73.1 \%$ ) place their satisfaction levels for Internet search results between high and low levels. People's expectations have risen along with the improvement of information technology. The results the users obtained within $30 \mathrm{~min}$ utes on the Internet might have taken them a few hours or days before this type of searching was available to researchers.

Another challenge for academic librarians is to find ways to assist students and faculty in their use of the Internet. The three major problems that respondents encounter when searching the Internet are: (1) do not find information needed, (2) no full-text information can be cited for academic study and/or research, and (3) too many hits. An easy solution to the problem of too many hits is to teach users better (narrower) search strategies.

The third challenge for academic librarians is to find ways to provide effective Internet search training. This issue is important because the students tend to believe that the responsibility of teaching them Internet searching belongs to university computing services and/or individual academic colleges. Of course, library faculty must continue discussions within the academic community to make sure that this area of teaching is their responsibility.

\section{Conclusions Opportunities}

The three challenges identified above present five additional opportunities for academic librarians:

1. The high percentage of students and faculty who use the Web on a daily or weekly basis for their academic studies affirms that information access delivered through the Internet is becoming an important component of library services in tomorrow's library.

2. Academic librarians will find that they need to reallocate budget resources to expand the availability of electronic resources for students and faculty. This will likely take the form of Internet delivery of commercial full-text databases. Internet access will be seen as an advantage for eliminating or reducing the need for CD-ROM towers, for receiving more timely updates from the database providers, and for providing 24-hour access to academic resources for students and faculty both on campus and in homes and offices.

3. In providing Internet training, academic librarians need to initiate and strengthen their relationships with their institution's computing services and also 


\begin{tabular}{|c|c|c|c|c|c|c|c|c|}
\hline \multicolumn{9}{|c|}{$\begin{array}{c}\text { TABLE } 12 \\
\text { Student and Faculty Opinions on Who Should Be } \\
\text { Responsible for Teaching Them How to Search } \\
\text { the Internet Effectively (question 12) }\end{array}$} \\
\hline & \multicolumn{2}{|c|}{ Undergraduate } & \multicolumn{2}{|c|}{ Graduate } & \multicolumn{2}{|c|}{ Faculty } & \multicolumn{2}{|c|}{$\mathrm{n}=786$} \\
\hline & $\mathrm{N}$ & $\%$ & $\mathrm{~N}$ & $\%$ & $\mathrm{~N}$ & $\%$ & $\mathrm{~N}$ & $\%$ \\
\hline Academic college & 271 & 34.5 & 36 & 4.6 & 3 & 0.4 & 310 & 39.5 \\
\hline University computing services & 272 & 34.6 & 62 & 7.9 & 16 & 2.0 & 350 & 44.5 \\
\hline University librarian faculty & 92 & 11.7 & 45 & 5.7 & 10 & 1.3 & 147 & 18.7 \\
\hline Other & 85 & 10.8 & 32 & 4.1 & 7 & 0.9 & 124 & 15.8 \\
\hline
\end{tabular}

with the academic disciplines. An instructional strength for academic librarians would be to work in academic partnership with classroom faculty to teach students how to effectively locate scholarly information and how to evaluate sites where information is found. A measure of success can be realized by helping students learn how to reduce the number of unrelated hits. Academic librarians may combine Internet search training with teaching about traditional library resources of books and journals. Not everything can be found on the Internet, and often it is quicker to find the information by looking at print materials.

4. Academic librarians need to effectively integrate the use of Internet search engines into instruction programs and at the reference desk because $657(83.6 \%)$ of the 786 respondents reported that using search engines is a preferred way to search the Internet. Also, librarians need to view Yahoo as a database of significance because $633(80.5 \%)$ of the 786 respondents identified it as a key resource.

5. Academic librarians who have de- veloped home pages need to find ways to publicize them because only 325 $(41.4 \%)$ of the 786 respondents reported that they visited the library's home pages. Academic librarians may wish to use the library's home pages to expand instructional programs for traditional bibliographic instruction by developing Webbased, self-paced teaching courses that allow students to learn and use academic library resources, online databases, and general Internet search.

\section{Suggestions for Further Investigations}

A number of further investigations can be suggested as a result of this survey:

- A Seton Hall University Library Internet User Survey should be conducted on a regular basis to compare possible changes in users' Internet search strategies and levels of satisfaction.

- The impact of Internet search training offered by academic librarians on user satisfaction should be studied.

- Experiments with providing Webbased bibliographic instructions through the library's home pages should be performed.

\begin{tabular}{|c|c|c|c|c|c|c|c|c|}
\hline \multicolumn{9}{|c|}{$\begin{array}{c}\text { TABLE 13 } \\
\begin{array}{c}\text { Students and Faculty Who Would Likely Attend Internet Training } \\
\text { Offered by University Librarian Faculty } \\
\text { (question 13) }\end{array} \\
\end{array}$} \\
\hline & \multicolumn{2}{|c|}{ Undergraduate } & \multicolumn{2}{|c|}{ Graduate } & \multicolumn{2}{|c|}{ Faculty } & \multicolumn{2}{|c|}{$\mathrm{n}=786$} \\
\hline & $\mathrm{N}$ & $\%$ & $\mathrm{~N}$ & $\%$ & $\mathrm{~N}$ & & $\mathrm{~N}$ & $\%$ \\
\hline Basic Internet searching & 256 & 32.6 & 80 & 10.2 & 11 & 1.4 & 347 & 44.2 \\
\hline Advanced Internet searching & 337 & 42.9 & 78 & 9.9 & 19 & 2.4 & 434 & 55.2 \\
\hline Gateway Internet resource listings & 175 & 22.3 & 54 & 6.9 & 11 & 1.4 & 240 & 30.6 \\
\hline Subscription databases & 124 & 15.8 & 52 & 6.6 & 16 & 2.0 & 192 & 24.4 \\
\hline
\end{tabular}


- Internet search engines should be studied and compared and ways sought to exploit the strength presented by Yahoo as a leading favorite Internet search engine and database.

The author would like to acknowledge the assistance of his colleagues for their critical reviews and helpful comments on his survey instrument, survey proposal, and final report: Beth Bloom, Paul Chao, Declan Cunniff, Arthur Häfner, Anthony Lee, Katalin Mandelker, Richard Stern, Joan Taub, and Charles Yen. He also thanks the many Seton Hall University faculty members and students for participating in the survey.

\section{Notes}

1. Mary J. Lynch, Electronic Services in Academic Libraries: ALA Survey Report (Chicago: ALA, 1996).

2. John C. Bertot, Charles R. McClure, and Douglas L. Zweizig, The 1996 National Survey of Public Libraries and the Internet: Progress and Issues: Final Report (Washington, D.C.: U.S. National Commission on Libraries and Information Science, 1996).

3. The original library home pages can be accessed at $<w w w . s h u . e d u / l i b r a r y /$ original.htm $>$

4. Helen M. Gothberg, "Library Survey: A Research Methodology Rediscovered," College $\mathcal{E}$ Research Libraries 51 (Nov. 1990): 553-59. In this article, Gothberg states: "Most descriptive surveys describe one library or a group of libraries within a system or even a state. Such surveys deal with quantitative data and are used to compare with similar statistics from the previous year, or other libraries. They may also seek opinions and/or demographic data about users."

5. Ibid.

6. John Neter, William Wasserman, and G. A. Whitemore, Applied Statistics (Boston: Allyn and Bacon, 1982), 188.

7. Arthur W. Häfner, Descriptive Statistical Techniques for Education, 2nd ed. (Chicago: ALA, 1998), 6 .

8. The University Office of Publications, Seton Hall University: Undergraduate Bulletin 19971998 (South Orange, N.J.: Seton Hall University), 7.

9. Floyd J. Fowler, Survey Research Methods (Newbury Park, Calif.: Sage, 1993), 40-41. 